\title{
UAV技術の海岸モニタリング測量への 現地適用性に関する検討
}

\author{
森 智弘 1 - 安藤 智史 $2 \cdot$ 大中 晋 $^{3} \cdot$ 近藤 $\quad$ 泰徳 2 -市川 真吾 ${ }^{3}$

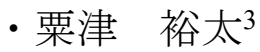 \\ 1 日本工営（株）コンサルタント海外事業本部（†102-8539 東京都千代田区九段北 1-14-6） \\ E-mail: mori-tm@n-koei.jp \\ 2 玉野総合コンサルタント（株）流域技術部（†461-0005 名古屋市東区東桜 2-17-14） \\ E-mail: andou_satoshi@tamano.co.jp \\ 3 正会員 日本工営（株）コンサルタント海外事業本部（干102-8539 東京都千代田区九段北 1-14-6） \\ E-mail: onaka-ss@n-koei.jp
}

\begin{abstract}
海岸モニタリング測量を実施する際，従来手法（レベル測量やトータルステーション）を用いての詳 細な測量は, 多大な時間・労力を要することや, 調査寸る人の熟練度によって, 精度にばらつきが生じ る可能性がある.UAV 測量の精度向上を目的として，3 次元モデルの設定值や基準点の配置と精度の関 係を検証した例はあるものの，UAV 測量に必要な現場作業の簡便化に着目して，精度を検証した事例 はまだ少ない，そこで本研究はUAV 測量による海岸モニタリングの現地適用性を検証することを目的 として, 標定点間隔の違い, 砂浜の標定点の有無, 撮影高度の違いが精度に与える影響を調べた。 その 結果，従来手法に比べ，大幅な現場作業の簡便化・省力化が図られる可能性があることが示された.
\end{abstract}

Key Words : UAV survey, beach topographic survey, beach monitoring, applicability on site

\section{1. 研究の背景および目的}

定期的な海岸モニタリング測量は，現地の土砂供給， 地形変化のメカニズムの理解や将来の変化予測をする上 で不可欠であるが，従来手法（レベル測量やトータルス テーション）を用いての詳細な測量は，多大な時間・労 力を要することや，調査する人の熟練度によって，精度 にばらつきが生じる可能性がある。一方，近年 UAV(Unmanned Aerial Vehicle)の普及に伴い，海岸・港湾 分野においては, 海岸地形変化のモニタリング1),2)や危険 を伴う消波ブロックの計測等へのUAV測量の適用3が検 討されている. 国内の公共測量にUAV測量を適用寸る場 合, 国土地理院「UAVを用いた公共測量マニュアル」4)(以 下，UAV測量マニュアルと記載）に準ずることが求めら れる，一方，海外においては，測量目的に応じて，求め られる精度も適宜判断されるとともに，相手国による実 施を考えると，できるだけ現場作業の簡便化を図ること が望まれる。これまでUAV測量の精度向上を目的として， 3次元モデルの設定值や基淮点の配置と精度の関係を検

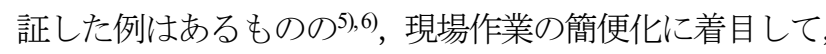
諸々の条件を変えて精度を検証した事例はまだ少ない。

そこで本研究は，モルディブのサンゴ礁海岸を例にと
り，UAV測量による海岸モニタリングの現地適用性を検 証することを目的として，UAV測量に必要な現地作業に 関わる諸条件を変えた場合の精度の比較検討を実施した。

\section{2. 検討方法}

(1) 対象海岸

モルディブ国 Addu 環礁のラグーン側に面したサンゴ

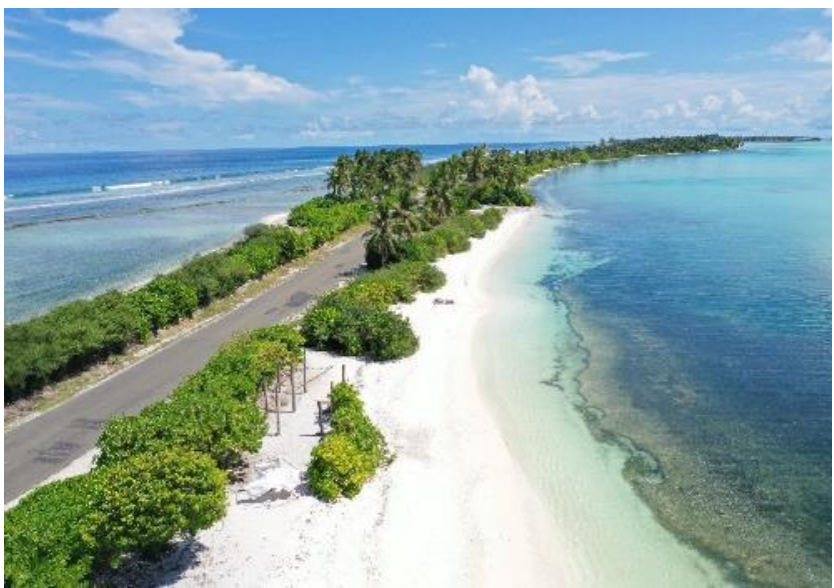

図-1＼cjkstart対象海岸の空中写真（南から北を望む） 


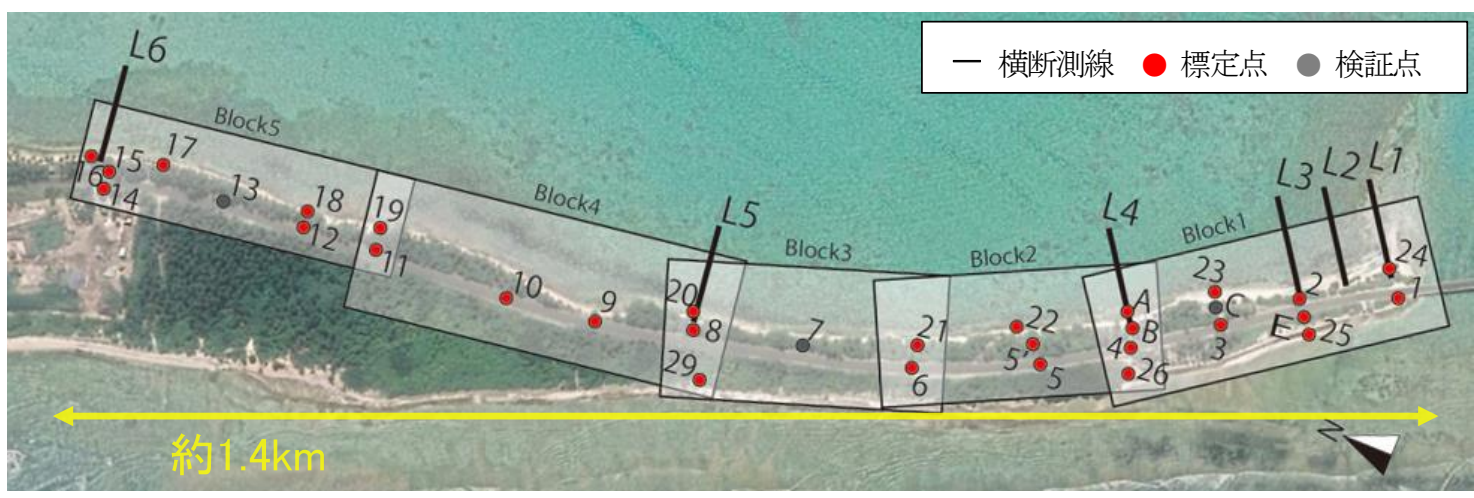

図-2 測量実施エリアの位置図および標定点・横断測線の配置図

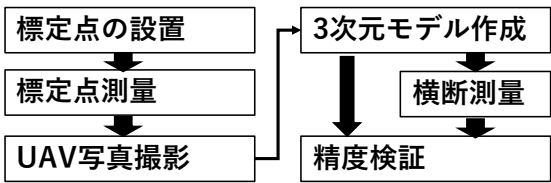

図-3 検討の実施手順フロー

礁海岸の約 $1.4 \mathrm{~km}$ 区間を対象として現地調査を実施した (図-1). 写真左側（北側）の外洋側が喼海岸であるのに対 し, 右側（南側）の測量実施海岸では, 白いサンゴ砂で 構成される砂浜海岸が広がる. 前浜勾配は $1: 8 \sim 1: 10$, バ 一ムトップ高は MSL $+1.5 \mathrm{~m}$ である. また陸側の道路標高 は MSL+1.2 m と, 低平な地形であることが特徽である.

\section{（2）標定点の設置および標定点測量}

3次元モデル作成時のXY（平面）およびZ（標高）の基 準となる標定点を，前述のUAV測量マニュアルを参考に, 道路上に概ね $2100 \mathrm{~m}$ 間隔，海岸線上に概ね $200 \mathrm{~m}$ 間隔で設 置した（図-2）. 標定点の座標值および標高はRTK-GNSS 測量より取得した.

\section{(3) UAV 撮影}

調査に用いたUAVの機体はDJI社のPhamtom4 Advanced, カメラは標準搭載 (2000万画素, 焦点距離は $24 \mathrm{~mm}$ ) のも のを使用した. オーバーラップは $80 \%$ ， サイドラップは $60 \%$ ，撮影高度は $42 \mathrm{mおよび} 84 \mathrm{~m}$ （地上画素寸法はそれ ぞれ $1.0 \mathrm{~cm}$ おび $2.0 \mathrm{~cm})$, 撮影間隔を 2 秒として, 自動飛 行アプリを用いたプログラム飛行により撮影した。 なお 飛行経路については，バッテリー容量と目視飛行が可能 な範囲を考慮し，撮影対象範囲をBlock 1 5の計5ブロッ クに分割するような飛行計画とした.

\section{(4) 画像処理}

画像処理(SfM)ソフトにはPix4社製のPix4Dmapperを用 い，RTK-GNSS測量によって取得した位置情報とUAVで 撮影した空中写真から3次元モデルを作成した.
表-1 検証点較差

\begin{tabular}{|l|l|l|}
\hline 検証点較差 & $\Delta \mathrm{XY}(\mathrm{m})$ & $\Delta \mathrm{Z}(\mathrm{m})$ \\
\hline 平均值 & 0.036 & 0.015 \\
\hline 標準偏差 & 0.040 & 0.035 \\
\hline 最大值 & 0.049 & 0.049 \\
\hline
\end{tabular}

本検討の実施手順フローを図-3に示す.

\section{3. 精度の検証}

\section{（1）検証点における精度の検証}

撮影高度 $42 \mathrm{~m}$ （地上解像度は $1.0 \mathrm{~cm}$ ), 標定点数を 29 点, 検証点を 3 点, の条件により作成した 3 次元モデル の検証点における XY 方向, およびZ 方向の較差を調べ た. 図-2の赤色点は標定点，灰色点は検証点を表す，検 証点較差の結果を表-1 に示寸. 較差の最大值は, XY 方 向で $0.049 \mathrm{~m}, \mathrm{Z}$ 方向で $0.049 \mathrm{~m}$ であったが，これは前述 のUAV 測量マニュアルで規定される地上画素寸法 $1 \mathrm{~cm}$ で空中写真を撮影した場合の位置精度 (XY 方向, Z 方向 ともに $0.05 \mathrm{~m}$ 以内）を満足することを確認した. これよ り以降の検討は, 本条件で作成した 3 次元モデルをべー スとして検討を行った.

\section{（2）横断地形測量との比較による精度の検証}

図-2 で示寸測線 L1〜L6 において，横断地形測量を害 施した．ここで L1 L4 は，岸沖方向の砂幅が比較的大き いエリア，L5 L6 は，楖子の根の状況や浜崖の形成等， 海岸侵食が顕著なエリアに位置する. 3 次元モデルから 作成した横断地形と，測量結果から得られた横断地形を 比較することにより，Z 方向の精度および横断地形形状 の比較を行った. 測点は海岸形状が岸沖方向に変化する 地点に設定した. ここでは, 横断地形の比較例として L3, L5 の結果を示す． L3, L5 の測点地点の位置を図-4，図-6 に，標高比較の結果を図-5, 図-7 に示す. 図-5より，L3 の横断地形の形状は, 3 次元モデルで精度良く再現され 


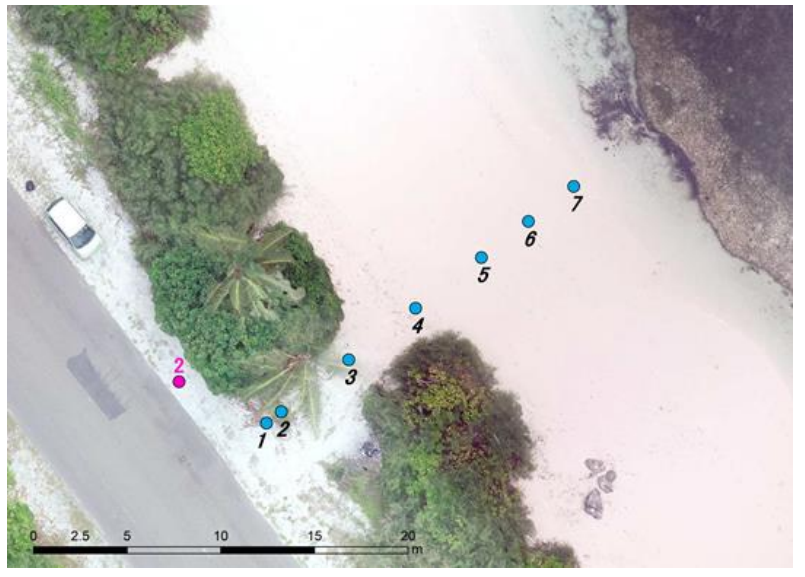

図-4 L3 の測点地点

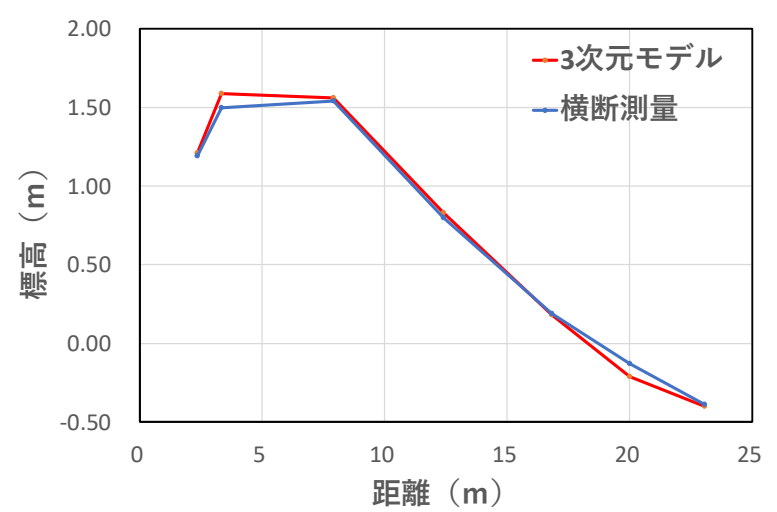

図-5Ｌ3における横断地形の比較

表-2＼cjkstart各測線におけるZ 方向の較差比較

\begin{tabular}{|r|c|c|c|}
\hline 横断測線 & $\begin{array}{c}\Delta \mathrm{Z} \\
\text { 平均値 } \\
(\mathrm{m})\end{array}$ & $\begin{array}{c}\Delta \mathrm{Z} \\
\text { 標淮偏差 } \\
(\mathrm{m})\end{array}$ & $\begin{array}{c}\Delta \mathrm{Z} \\
\text { 最大值 } \\
(\mathrm{m})\end{array}$ \\
\hline $\mathrm{L} 1$ & 0.021 & 0.020 & 0.06 \\
\hline $\mathrm{L} 2$ & 0.008 & 0.007 & 0.02 \\
\hline L3 & 0.037 & 0.031 & 0.09 \\
\hline L4 & 0.035 & 0.027 & 0.08 \\
\hline L5 & 0.035 & 0.015 & 0.06 \\
\hline L6 & 0.040 & 0.040 & 0.12 \\
\hline
\end{tabular}

ており，Z方向較差は $0.09 \mathrm{~m}$ 以内であった. 図-7 より, L5 地点で見られる浜崖形状も精度良く再現されており, Z 方向較差は $0.05 \mathrm{~m}$ 以内であった.

\section{ここで，L3, L5 以外の測線における Z 方向較差の平均} および標準偏差についても議論するために，L1 L6 の全 測線において, 測量結果と 3 次元モデルの各測点の Z 方 向較差の平均值，標準偏差，最大值を整理したものを表 -2, 平均值および標準偏差を取り出してグラフ化したも のを図-8に示す.いずれの測線においても Z方向の較差

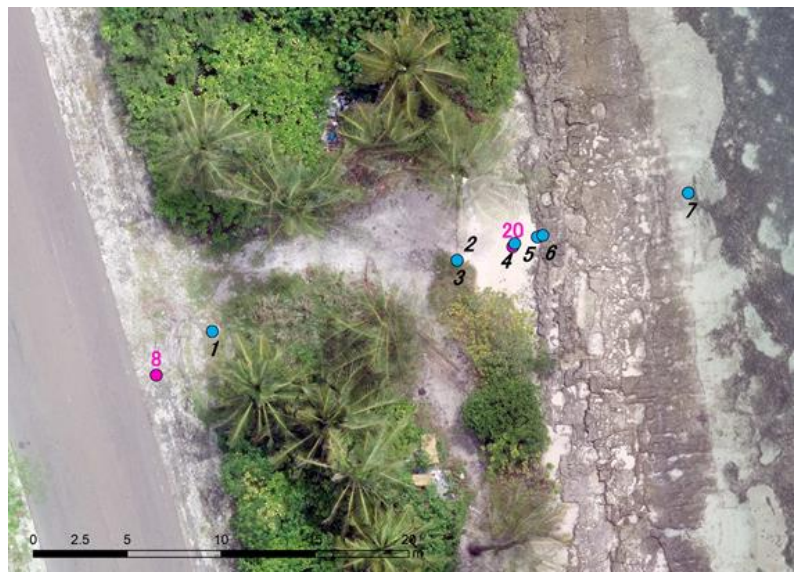

図-6 L5 の測点地点

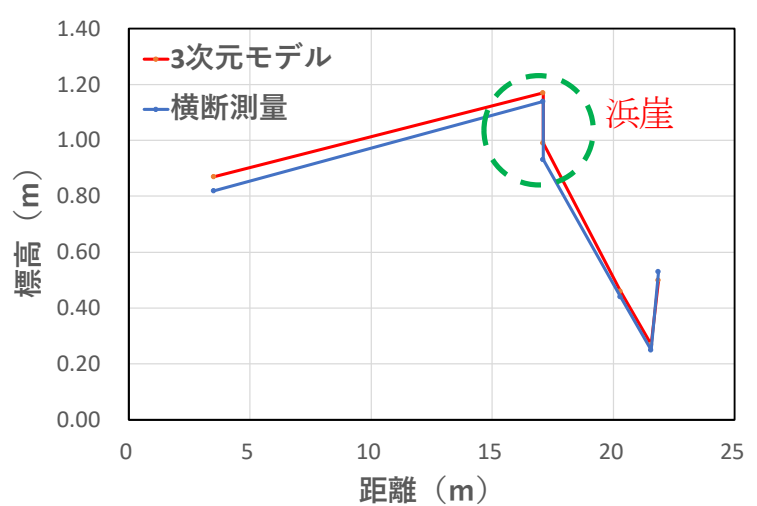

図-7 L5における横断地形の比較

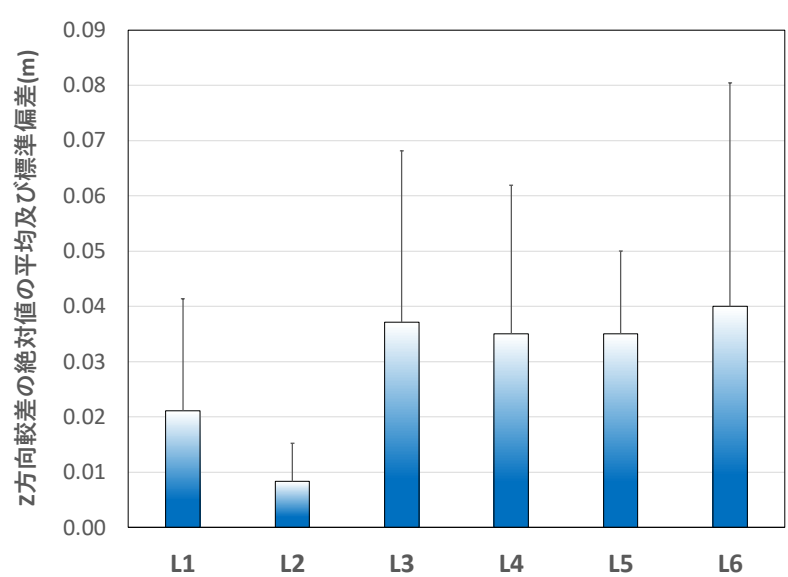

図-8 測線 L1〜L6 における Z 方向の較差の絶対值の平均と 標準偏差

の最大值が $0.12 \mathrm{~m}$ 以内, 較差の平均が $0.04 \mathrm{~m}$ 以内とな った. 前述の UAV 測量マニュアルでは $0.05 \mathrm{~m}$ 以内の位 置精度が求められるため, 平均が $0.04 \mathrm{~m}$ 以内という結果 は, UAV 測量の海岸モニタリングへの適用を考えた場合， 充分な精度が確保されたといえる.

なお, 表-2 において L1 L6 の Z 方向の較差の最大值が 0.02 0.14 と，ややバラツキがある值となっているが，こ 
表-3 検討ケース

\begin{tabular}{|c|c|c|}
\hline \multirow{2}{*}{$\begin{array}{l}\text { 標 } \\
\text { 定 } \\
\text { 点 } \\
\text { 数 }\end{array}$} & a) 標定点間隔 & $\begin{array}{l}\cdot 100 \mathrm{~m} \text { おきに } 1 \text { 点 } \\
\cdot 200 \mathrm{~m} \text { おきに } 1 \text { 点 } \\
\cdot 300 \mathrm{~m} \text { おきに } 1 \text { 点 }\end{array}$ \\
\hline & $\begin{array}{l}\text { b) 砂浜の標定点 } \\
\text { の有無 }\end{array}$ & $\begin{array}{l}\text { ・道路上 } 200 \mathrm{~m} \text { おきに } 1 \text { 点 } \\
\text { ・道路上 } 200 \mathrm{~m} \text { おきに } 1 \text { 点 } \\
\text { および砂浜上 } 200 \mathrm{~m} \text { おきに } 1 \\
\text { 点 }\end{array}$ \\
\hline & c) 撮影高度 & $\begin{array}{l}\cdot 42 \mathrm{~m} \text { （地上解像度 } 1 \mathrm{~cm} \text { ） } \\
\cdot 84 \mathrm{~m} \text { （地上解像度 } 2 \mathrm{~cm} \text { ) }\end{array}$ \\
\hline
\end{tabular}

れは 3 次元モデルと横断測量の水平位置のずれにより， Z 方向に較差が生じたためと考えれる.

\section{(3) 現場作業の効率化に関する検討}

現場作業の簡便化・省力化を図れる可能性について調 べるために，標定点間隔，撮影高度を変えた場合の精度 検証を実施した．検討ケース a)〜 c)を表-3 に示す.

\section{a)＼cjkstart標定点間隔の違いによる精度影響}

標定点の配点間隔の違いが 3 次元モデルの精度に与え る影響を調べた．標定点間隔の異なる 3 ケース (100 m, $200 \mathrm{~m}, 300 \mathrm{~m}$ )で実施した精度検証結果を図-9 に示す. 赤 線は XY 方向の較差の平均, 青線は $\mathrm{Z}$ 方向の較差の平均 を示しているが，XY 方向の較差は間隔に依らずほぼ一 定であったのに対して，Z 方向の較差は間隔が大きくな るほど増大する傾向が見られた．XY 方向の較差の平均 は，間隔によらず，いずれのケースも $0.03 \mathrm{~m}$ 以内と，精 度が高い結果となった。一方， $\mathrm{Z}$ 方向の較差の平均は, 間隔が $200 \mathrm{~m}$ のケースでは $0.05 \mathrm{~m}$ ，間隔が $300 \mathrm{~m}$ のケー スでは $0.19 \mathrm{~m}$ であった. UAV 測量の海岸モニタリング 測量への適用を考えた場合，Z 方向の位置精度は $0.10 \mathrm{~m}$ 以内であれば充分許容できると考えられることから，間 隔を $200 \mathrm{~m}$ まで広げても, 実務上適用可能と判断される.

\section{b）砂浜の標定点の有無による精度影響}

前述までの検討では，標定点は道路上と砂浜上に配置 している.ここでは，標定点を道路上のみに配置した場 合における， 3 次元モデルの精度に与える影響を調べた. 標定点間隔は前述の a）で海岸測量に充分な精度が確認 できた $200 \mathrm{~m}$ を採用し，砂浜上の標定点を除外した道路 上のみの標定点を用いたケース, および道路+砂浜上の標 定点を用いたケースでの精度検証を行った。 なお本検討 では，砂浜の標定点の有無のみによる違いに着目するた め, 両ケースの標定点数が極力同程度となるように調整 した. 図-10 上図が砂浜上の標定点を除外し, 道路上の $200 \mathrm{~m}$ 毎に 1 点配置したケース（標定点数は 11 点）, 下

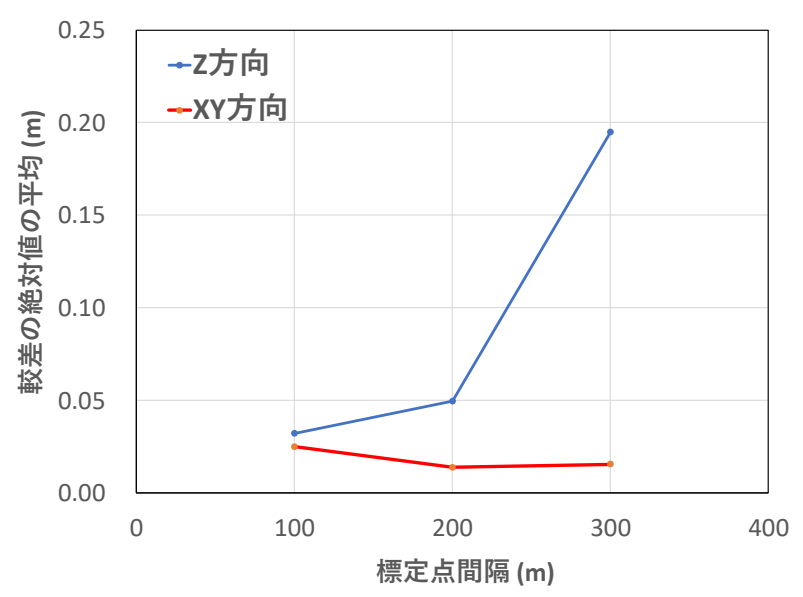

図-9 L1〜L6 におけるZ 方向較差の絶対值の平均と 標準偏差

図が，道路上の $200 \mathrm{~m}$ 毎に 1 点，およひ砂浜上の $200 \mathrm{~m}$ 毎 に 1 点を配置したケース（標定点数は 14 点）を示す.た だし，前者の道路上のみの標定点を用いたケースにおい ては，モデルの両端では砂浜上の標定点を含むようにし た.これは，写真測量の特性上，両端が 1 点の場合はモ デルの誤差が大きく生じやすいという写真測量における 一般的な知見に基づき, 両端を 2 点としたものである7).

道路上のみのケースと, 道路十砂浜上のケースの精度検 証結果を XY 方向と $\mathrm{Z}$ 方向に分けて示したものが図-11 である.両ケースを比較すると，XY および Z 方向共に 較差の違いはほとんどみられず，XY 方向の較差の平均 はいずれも $0.03 \mathrm{~m}$ 以内, $\mathrm{Z}$ 方向の較差の平均は $0.06 \mathrm{~m}$ 以 内であったことから，道路の標定点のみを使用した場合 でも海岸測量に充分な精度を確保できたといえる．標定 点を岸沖方向に近い位置に複数設置しても，位置精度へ の影響が小さかったのは, 対象範囲の岸沖方向の長さ (砂 浜幅）が沿岸方向の長さに比べて充分小さかったことが 影響していると考えられる.

以上より, 標定点間隔を $200 \mathrm{~m}$ とした場合については, 標定点を 1 点ずつ配置するのみで必要な精度が確保され たことから，現場作業の簡便化および省力化を罒れるこ とが示された。

\section{c）撮影高度の違いによる精度影響}

つぎに, 空中写真の撮影高度が 3 次元モデルの精度に 与える影響を検証した。 これまでの検討の対象範囲は, 図-2 の Block 1 5 であったが, Block ごとの精度の違いは ほとんど見られなかった。 そこで，ここでは対象範囲を 


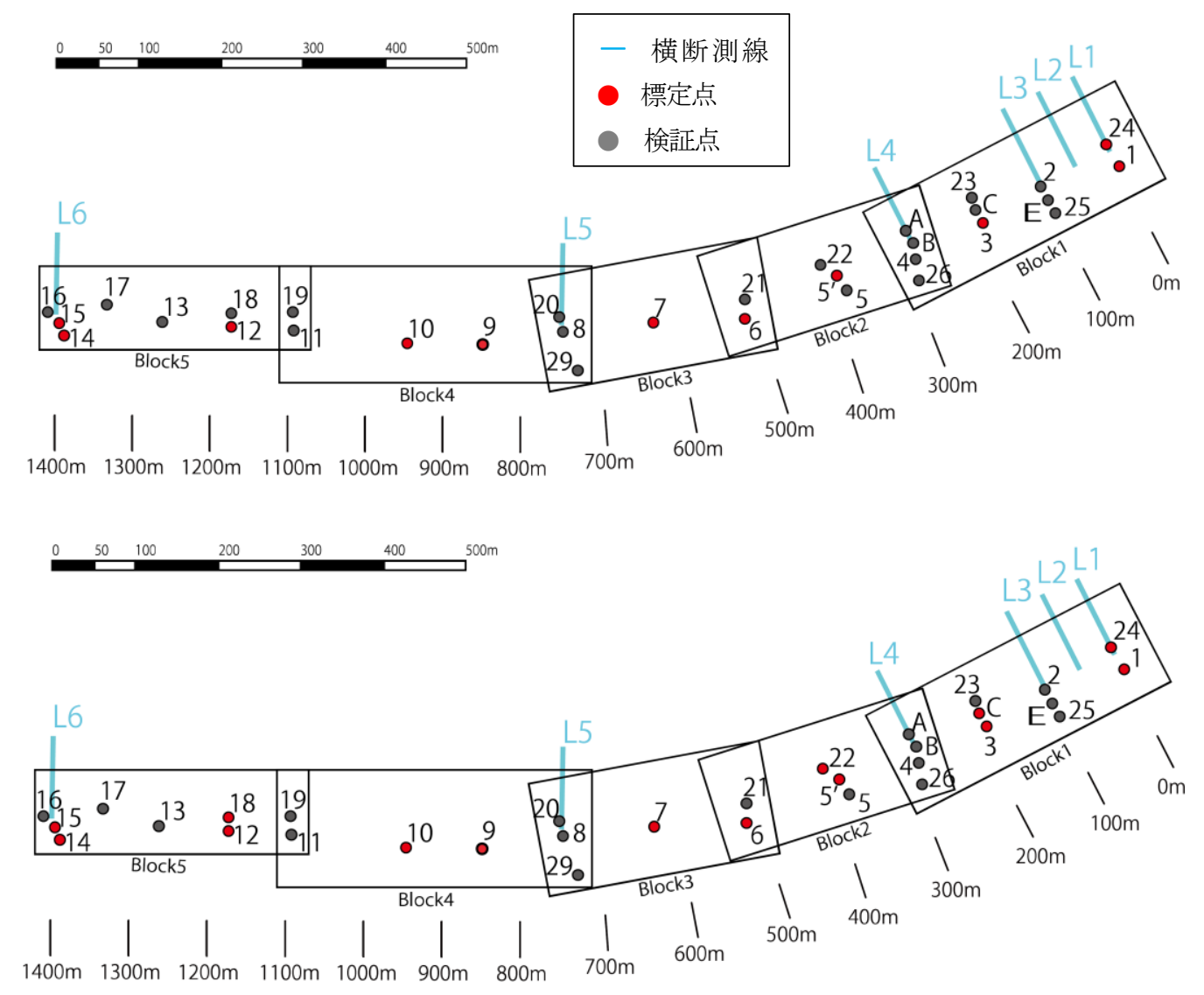

図-10 砂浜上の標定点の有無による精度検証の標定点配置図

（上 : 砂浜上の標定点を除外したケース，下：砂浜上の標定点を含むケース）

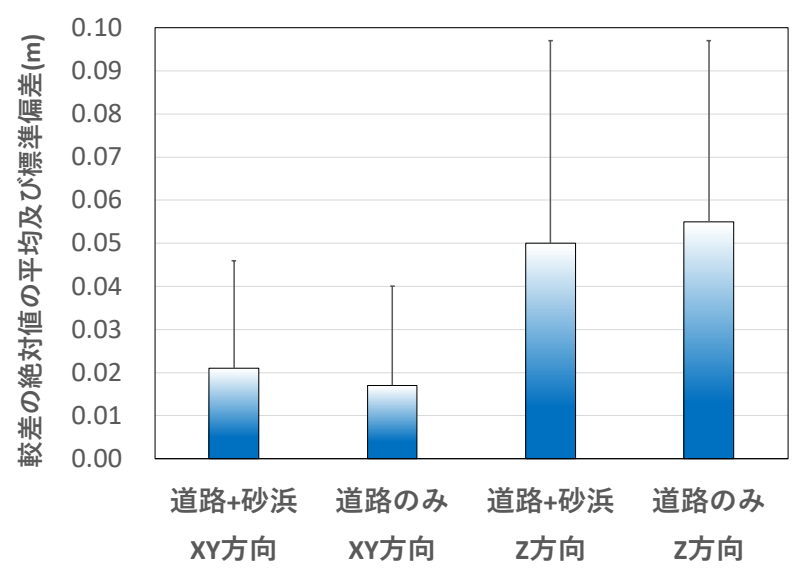

図-11 砂浜の標定点の有無による精度検証結果

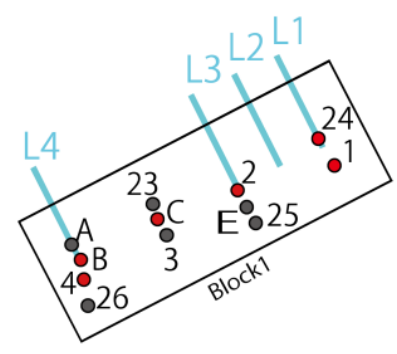

図-12＼cjkstart撮影高度の違いによる精度検証の標定点配置図

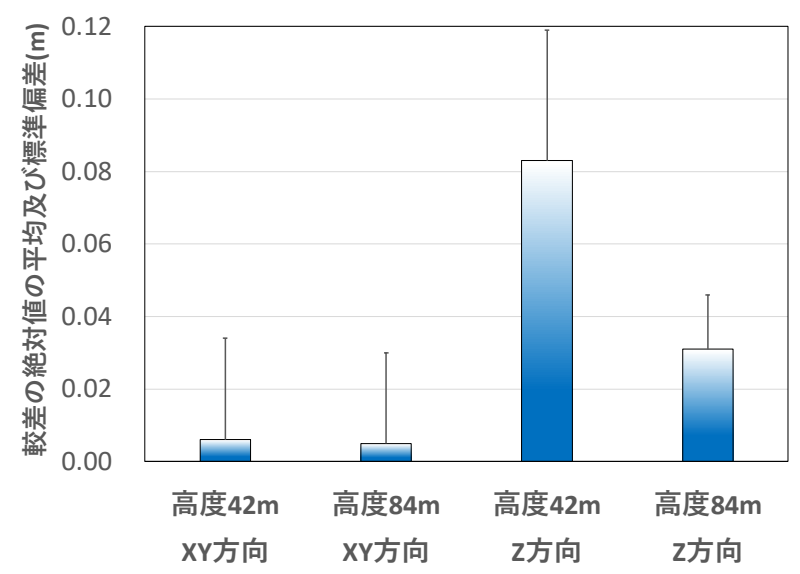

図-13 撮影高度の違いによる精度検証結果

図-12 に示す Block 1 のみとし，標定点は 6 点を使用し た.この対象範囲における, 高度 $42 \mathrm{~m}$, 高度 $84 \mathrm{~m}$ (地上 解像度はそれぞれ $1 \mathrm{~cm}, 2 \mathrm{~cm}$ ) の 2 ケースの精度検証結 果を図-13 に示す. XY 方向の較差は，高度の違いによる 有意な差はみられなかった。一方，Z 方向の較差につい ては, 高度 $84 \mathrm{~m}$ のケースの方が高い精度が得られ, 高度 $42 \mathrm{~m}$ より $0.05 \mathrm{~m}$ 程小さくなった. UAV 測量では, 撮影 高度が高いほど，画像の解像度が低下するため, 精度が 落ちるのが一般的である. 一方で, 前述のUAV 測量マニ 
ユアルによると，計測対象範囲において，マッチングし やすい目印が多ければ，3 次元形状復元計算における画 像マッチングの精度が向上することが示されている.こ れより，本結果で得られた $\mathrm{Z}$ 方向の較差の逆転現象は, 複数の写真の画像マッチングの精度の違いが影響してい る可能性がある. 対象範囲の Block1 内では，ほとんどが 白い砂浜域であり, 均一で画像上の特徵点が少なかった。 このため，高い高度から俯瞰した方が，マッチングの目 印となる画像間の特徵点を認識しやすくなり, その結果, 画像マッチングの精度が向上した可能性がある。なお， 本研究では Block1 のみで高度の違いによる精度比較を 行ったが，画像上の特徽点の異なる他のエリアにおける 精度への影響については，更に検討が必要である.

\section{4. 結論}

本研究で得られた結論を以下にまとめる.

(1) 撮影高度 $42 \mathrm{~m}$ (地上解像度は $1.0 \mathrm{~cm}$ ), 標定点数 を 29 点, 検証点を 3 点, の条件により作成した 3 次元モ デルの位置精度は，XY 方向，Z 方向ともに $0.05 \mathrm{~m}$ 以内 となった.

（2）設置する標定点の間隔 (および数量) は，XY 方向 の精度に比べて Z 方向の精度に大きく影響することが確 認された。

（3）設置する標定点の間隔が大きくなるほど，3 次元 モデルの Z 方向の精度は低下寸る. 一方，XY 方向の精 度は大きな差は見られなかった。

（4） 3 次元モデルと横断測量の比較結果により，同じ 測線内では道路側や砂浜側といった場所の違いによる精 度の違いは確認されなかった。

（5）標定点を道路上のみに設置した場合と，道路と砂 浜上に設置した場合の XY 方向，およびZ 方向の精度に 大きな違いはなかった。

（6）撮影高度 $42 \mathrm{~m}$ の場合と $84 \mathrm{~m}$ とした場合の Z 方向 の精度は，高度 $84 \mathrm{~m}$ の方が高度 $42 \mathrm{~m}$ より高くなった.
本検討対象海岸のようなサンゴ砂で構成される白い砂浜 海岸では，高い高度の方が画像マッチングの精度が向上 し, 精度が高くなったと考えられる. 一方, XY 方向の精 度に大きな違いは確認されなかった。

海岸モニタリングは，定期的かつ継続的にデータを蓄 積していく必要があることから，現地および解析作業を 簡便化・省力化していくことが望まれる．UAV 技術を用 いた海岸モニタリングでは，求められる精度を満たす範 囲で，適切な標定 点の配置や個数，撮影高度を適宜設 定することで，従来手法に比べ，大幅な現場作業の簡便 化・省力化が図られる可能性があることが示された。

謝辞 : 本論文は，独立行政法人国際協力機構 (JICA) に より，2018 年からモルディブで実施されている調査成果 の一部を取りまとめたものである、本事業の実施に係つ た各関係機関の方々に謝意を表します。

\section{参考文献}

1) 松葉義直，佐藤愼司，波多野景治：静岡県福田浅羽海 岸サンドバイパス吐出口周辺における UAV を用いた 地形変化監視手法の適用, 海岸工学論文集, 第 72 巻 pp. 853-858, 2016.

2) 鈴木 彰容，三戸部 佑太，田中 仁，Volker ROEBER : UAV を用いた高頻度海浜モニタリング，海岸工学講 論文集，第 73 巻 pp.661-666， 2017.

3) 佐野朝昭, 綿貫啓: 漁港施設の維持管理における UAV の活用事例, 日本水産工学会誌，第 54 巻 pp.115-120, 2017.

4) 国土交通省国土地理院：UAV を用いた公共測量マニ ユアル (案) (平成 29 年 3 月改正)，2017.

5)菊雅美，森勇人：UAV-SfM/MVS 測量による砶浜海岸 の地形変化計測に関する研究, 土木学会論文集 B3（海 洋開発），第 75 巻 pp. 127-132， 2019.

6) 大矢 陽介, 伊藤 広高, 小濱 英司 : 無人航空機を用い た係留施設の地震時残留変位計測における基準点配 置と計測精度，土木学会論文集 B3（海洋開発），第 75 巻 pp. 133-138, 2019.

7) 秋山実 : 写真測量, p183, 山海堂, 2001.

(Received February 6, 2020)

(Accepted May 1, 2020)

\title{
APPLICABILITY ON-SITE FOR BEACH MONITORING BY UAV SURVEYING
}

\author{
Tomohiro MORI, Satoshi ANDO, Susumu ONAKA, \\ Yasunori KONDO, Shingo ICHIKAWA and Yuta AWAZU
}

There are some existing studies on the relationship between the set values of 3D models and the accuracy or the arrangement of reference points and the accuracy for the purpose of improving the accuracy of UAV surveying. In this study, the relationship between and the condition related to field work and the accuracy was evaluated for the purpose of verifying the applicability of beach monitoring by UAV survey. As a result, it was shown that the field work could be simplified depending on the purpose of the beach monitoring survey. 